\title{
Changes in Carbohydrate and Ribulose Bisphosphate Carboxylase-Oxygenase Contents in Peach Leaves after Applications of Different Amounts of Nitrogen Fertilizer
}

\author{
Naosuke $\mathrm{Nii}^{1}$, Katsushi Yamaguchi ${ }^{2}$ and Mikio Nishimura ${ }^{2}$ \\ ${ }^{1}$ College of Agriculture, Meijo University, Tempaku, Nagoya 468 \\ ${ }^{2}$ Department of Cell Biology,National Institute for Basic Biology, Okazaki 444
}

\begin{abstract}
Summary
The effects of applying different amounts of nitrogen on the accumulation of nonstructural carbohydrate and ribulose bisphosphate carboxylase-oxygenase (RuBisCO) and on some characteristics of peach leaves were determined on young trees. The leaf nitrogen contents of trees supplied 0 and $1.5 \mathrm{~g} \mathrm{~N} /$ pot $(\mathrm{N}-0$ and $\mathrm{N}-1.5$, respectively) were lower than were those administered $9.0 \mathrm{~g} /$ pot $(\mathrm{N}-9)$. On a dry weight (DW) basis, leaves sampled from $\mathrm{N}-0$ trees and $\mathrm{N}-9$ trees were $1.8 \%$ and $4.0 \%$, respectively. The chlorophyll content per unit leaf area increased with increased nitrogen applied. The starch content on a dry weight basis was inversely proportional to the amount of nitrogen administered, whereas total soluble sugar per unit dry weight was proportional. The sorbitol and sucrose contents per unit leaf fresh weight were the lowest in leaves from $\mathrm{N}-0$ trees. The $\mathrm{RuBisCO}$ content detected by immunoblotting after SDS-polyacrylamide gel electrophoresis as well as by immunostaining of sections under the light microscope in. creased with the increase in the amounts of nitrogen applied.
\end{abstract}

\section{Introduction}

Nitrogen is a very effective fertilizer for tree growth in most soil. Generally, the volume and capacity of sink organs with vigorous vegetative growth increase with increased soil application of nitrogen to fruit trees. Leaf starch content decreases with the application of nitrogen (DeJong et al., 1984; Nii et al., 1993), because the rate of export of photoassimilates from fully expanded leaves may be stimulated by vigorous vegetative growth. By contrast, with decreases in sink capacity due to limited application of nitrogen, starch increases in the leaves of fruit-trees, whereas chlorophyll and the rate of photosynthesis $(\mathrm{Pn}) \mathrm{de}$ creases (DeJong, 1982, 1983; DeJong et al., 1984; $\mathrm{Nii}$ et al., 1993). Although some information is available about the changes in starch content of leaves upon the application of nitrogen, the changes in contents of other carbohydrates in fruit trees have not been reported in detail. The photo-

Received; August 30, 1996. Accepted; February 24, 1997 synthetic activity of leaves is significantly related to the concentration of sugars translocated in the phloem. In general, there is a negative correlation between sucrose content and $\mathrm{Pn}$ in many plant species (Sawada et al., 1986, 1987; Tschaplinski and Blake, 1989).

Peach trees are woody species of Rosaceae in which the main translocatable carbohydrate is sorbitol (Webb and Burley, 1962; Williams et al., 1967; Bieleski, 1969). In the Prunus spp, there have been a number of reports on the relationship between $P n$ and the sorbitol content of leaves. Layne and Flore (1993) reported that the increase in $P_{n}$ in partially defoliated plants was associated with reduced starch content in leaves and elevated sucrose and sorbitol contents in sour cherry trees. In a more recent study, they concluded that the diurnal decline in $\mathrm{Pn}$ in defoliated plants is associated with an increase in the contents of sucrose and sorbitol in leaves (Layne and Flore, 1995). They also noted that they were unware of any other current reports that linked the content of sorbitol in leaves to the inhibition of photosynthe- 
sis in source leaves.

Several researchers have indicated that there is a good correlation between leaf nitrogen content and the $\mathrm{Pn}$ in woody plants (Mooney et al., 1978; Gulmon and Chu, 1981; DeJong, 1982, 1983; DeJong et al., 1984; DeJong and Doyle, 1985; Williams and Smith, 1985; Nii et al., 1993). It is important to understand how changes in the anatomy and biochemical composition of leaves are related to the soil application of nitrogen. Ribulose bisposphate carboxylase-oxygenase (RuBisCO) is one of the most important photosynthetic enzymes in leaves and accounts for more than $50 \%$ of the soluble in chloroplasts. The RuBisCO content which changes with the accumulation of starch in the chloroplasts ( $\mathrm{Nii}$ et al., 1995) has been estimated by immunostaining sections of leaves embedded in Technovit resin (Kuroiwa, 1991). Together with the changes in content of the RuBis$\mathrm{CO}$ protein that can be detected by immunoblotting after electrophoresis on polyacrylamide gels, results of immunocytochemical analysis are very useful for the characterization of leaf composition.

In the present experiments we applied different amounts of nitrogen to young peach trees and followed the changes in leaf area, leaf dry weight per unit leaf area (SLW), and chlorophyll content. We also measured contents of nonstructural carbohy. drate, including starch and sorbitol, and monitored changes in the content of RuBisCO protein.

\section{Materials and Methods}

\section{Plant materials}

Three-yr-old peach trees (Rrunus persica (L.) Batsch. cv. Ohkubo) grown in the open air in 30 . $\mathrm{cm}$ diameter pots (volume, 121) filled with sandy soil were treated on March 15 and May 15, 1994, with $\mathrm{NH}_{4} \mathrm{NO}_{3}$ fertilizer as follows: zero nitrogen per pot $(\mathrm{N}-0) ; 1.5 \mathrm{~g} / \operatorname{pot}(\mathrm{N}-1.5) ; 3.0 \mathrm{~g} / \operatorname{pot}(\mathrm{N}-3)$; $6.0 \mathrm{~g} /$ pot $(\mathrm{N}-6)$, and $9.0 \mathrm{~g} /$ pot $(\mathrm{N}-9)$. Other minerals applied to the trees were $\mathrm{Ca}\left(\mathrm{H}_{2} \mathrm{PO}_{4}\right)_{2} \cdot \mathrm{H}_{2} \mathrm{O}(1.0$ g per pot), $\mathrm{K}_{2} \mathrm{SO}_{4}(1.0 \mathrm{~g})$, and $\mathrm{MgSO}_{4} \cdot 7 \mathrm{H}_{2} \mathrm{O}(0.5$ g). Five plants were used per treatment, with the single exception that 10 plants were subjected to $\mathrm{N}-0$ treatment. The trees which grew continuously until the middle of May were not pruned.

Mature leaves on the fifth to seventh nodal positions on the current shoots in the first growth cycle were sampled from each tree at 9 a.m. on June
14 and the shoot length recorded.

Quantitation of chlorophyll, carbohydrate, and nitrogen

Chlorophyll content was measured by using five leaf discs $(8 \mathrm{~mm}$ in diameter). Chlorophyll was extracted with $100 \%$ ethanol and quantified by the method of Wintermans and De Mots (1965). Chlorophyll content is expressed per unit leaf area.

The total soluble carbohydrate content was determined with the anthrone reagent after extraction with $80 \%$ ethanol. To determine the starch content of leaves, the ethanol-insoluble residue was boiled to hydrate the starch grains and after cooling, it was incubated with glucoamylase for 2 hr. The mixture was then filtrated and an aliquot of the filtrate was analyzed. with the anthrone reagent.

The sorbitol and sucrose contents were determined by HPLC (Nii et al., 1994). A 1.0-g (fresh weight) leaf sample was macerated in $5 \mathrm{ml}$ of dis. tilled water at $4^{\circ} \mathrm{C}$ Three drops of $2 \%$ sulfosalicylic acid were added with a Pasteur pipette to the homogenate, which was then filtered through a $0.45-\mu \mathrm{m}$ filter. A $10^{-} \mu 1$ aliquot of the filtrate was injected into an HPLC system equipped with a Shodex-CH-801: column (Showa Denko K. K., Japan). The column was eluted with water at a flow rate of $1 \mathrm{ml} \mathrm{min}^{-1}$.

The nitrogen in leaves was quantitated by the Kjeldahl method.

\section{Electrophoresis and immunoblotting for detection of} RuBisCO protein

A $1.0 \mathrm{~g}$ (FW) leaf sample was macerated in a mortar with a pestle that had been chilled with liquid nitrogen with $5 \mathrm{ml}$ of $50 \mathrm{~mm}$. Tris-HCl buffer ( $\mathrm{pH}$ 8.0). The homogenate was centrifuged at $12,000 \times \mathrm{g}$ for $5 \mathrm{~min}$ at $4^{\circ} \mathrm{C}$ and the supernatant was subjected to SDS-PAGE $(12.5 \%$ acrylamide) as described by Laemmli (1970). The proteins were separated on the gel, and blotted electrophoretically onto a cellulose nitrate membrane (Schleicher and Schuell, Dassel, Germany). Antibodies against $\mathrm{RuBisCO}$ from spinach were prepared as described; previously (Nishimura and Akazawa, 1974). Immunologic reactions were detected with a second antibody conjugated with alkaline phosphatase, as described previously (Tsugeki et al., 1993). 


\section{Immuno-localization of RuBisCO protein}

For anatomical observations, the central area of the lamina was excised and fixed overnight in $4 \%$ paraformaldehyde in $0.1 \mathrm{M}$ cacodylate buffer ( $\mathrm{pH}$ $7.2)$ at $4^{\circ} \mathrm{C}$. The fixed specimens were dehydrated through a graded ethanol series and embedded in Technovit resin (Kulzer, Germany). To observe the RuBisCO protein, thin sections $(0.5 \mu \mathrm{m})$ were immunostained with monospecific antibodies against RuBisCO proteins from spinach and with a second antibody conjugated with rhodamine. Immunostained sections were examined by epifluorescence microscopy (Hayashi et all., 1995).

\section{Results and Discussion}

The soil applications of different amounts of nitrogen resulted in a linear relationship between amounts applied and leaf $\mathrm{N}$. Thus, leaf $\mathrm{N}$ were: $1.8 \%$ in $\mathrm{N}-0$ trees, $2.2 \%$ in $\mathrm{N}-1.5$ trees, $3.1 \%$ in $\mathrm{N}-3$ trees, $3.6 \%$ in $\mathrm{N}-6$ trees, and $4.0 \%$ in $\mathrm{N}-9$ trees.

With increased application of nitrogen, the length of current shoots, leaf area, and chlorophyll content of peach trees increased but SLW was not obviously attected (Fig. 1, Table 1). Mean leaf area was smallest in $\mathrm{N}-0$ and $\mathrm{N}-1.5$.

The total soluble sugar content in leaves increased proportionately to the nitrogen added (Table 2), but starch content was inversely proportionate. Figure 2 shows the relationship between total soluble sugar and starch content and the leaf-N. These results are similar to those obtained with kiwifruit and peach trees (DeJong et al., 1984, Nii et al., 1993): the leaves of nitrogendeprived plants had lower leaf-N and chlorophyll but a higher starch content than did leaves of plants with sufficient $\mathrm{N}$.

The sorbitol and sucrose content in leaves grown with sufficient nitrogen was higher than of $\mathrm{N}$ deprived leaves (Table 2). Similar results were reported in apple trees (Nii et al., 1997), but the differences were small. The volume and capacity of sink organs increased with shoot elongation

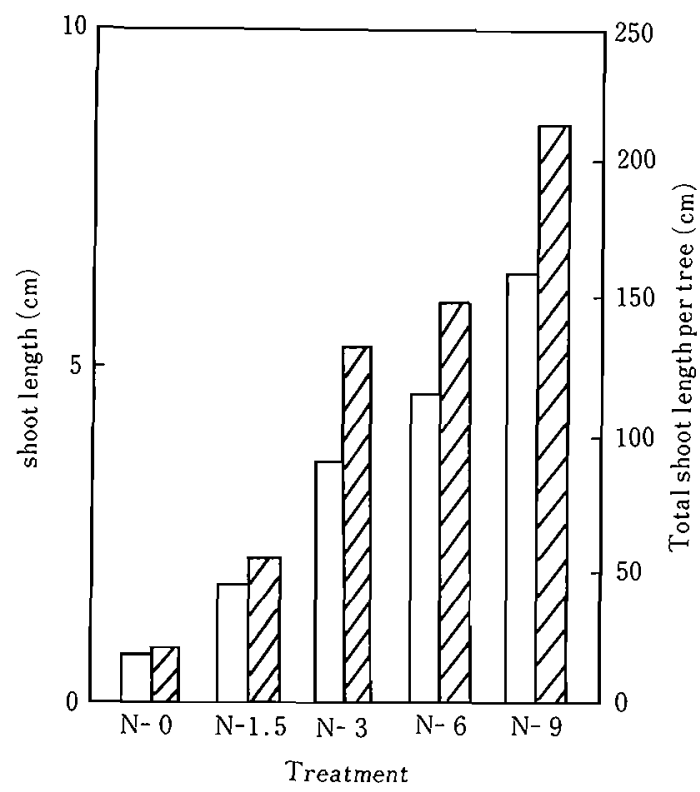

Fig. 1. Effects of differential applications of nitrogen on shoot elongation of peach trees. $\square$, Average shoot length; $Q I I$, , total shoot length per tree. See text for definitions of treatments.

Table 1. Effects of differential applications of nitrogen on leaf characteristics of peach trees.

\begin{tabular}{ccccc}
\hline $\begin{array}{c}\text { Amount of nitrogen } \\
\text { (g per pot) }\end{array}$ & $\begin{array}{c}\text { Leaf area } \\
\left(\mathrm{cm}^{2}\right)\end{array}$ & $\begin{array}{c}\text { Dry weight per } \\
\text { unit leaf area } \\
\left(\mathrm{mg} \mathrm{cm}^{-2}\right)\end{array}$ & $\begin{array}{c}\text { Total } \\
\text { chlorophyll } \\
\left(\mu \mathrm{g} \mathrm{cm}^{-2}\right)\end{array}$ & \multicolumn{2}{c}{$\mathrm{chl} \mathrm{a} / \mathrm{chl} \mathrm{b}$} \\
\hline 0 & 34.3 & 6.7 & 23.6 & 2.63 \\
1.5 & 31.8 & 7.8 & 39.6 & 2.70 \\
3.0 & 41.3 & 7.0 & 53.5 & 2.76 \\
6.0 & 44.6 & 6.6 & 57.6 & 2.80 \\
9.0 & 41.2 & 6.8 & 62.1 & 2.61 \\
L.S.D. $5 \%$ & 6.4 & 0.8 & 4.7 & 0.20 \\
& $1 \%$ & 1.0 & 6.4 & $\mathrm{NS}$ \\
\hline
\end{tabular}

Values are means of results from five trees in each case, with the exception of trees that did not receive any added nitrogen. In the latter case, ten trees were examined. 
Table 2. Effects of differential applications of nitrogen on the carbohydrate content of peach leaves.

\begin{tabular}{ccccc}
\hline $\begin{array}{c}\text { Amount of nitrogen } \\
\text { (g per pot) }\end{array}$ & $\begin{array}{c}\text { Total soluble } \\
\text { sugar }(\% \mathrm{DW})\end{array}$ & $\begin{array}{c}\text { Starch } \\
(\% \mathrm{DW})\end{array}$ & $\begin{array}{c}\text { Sorbitol } \\
(\% \mathrm{FW})\end{array}$ & $\begin{array}{c}\text { Sucrose } \\
(\% \mathrm{FW})\end{array}$ \\
\hline 0 & 6.5 & 8.2 & 2.5 & 0.7 \\
1.5 & 6.7 & 8.1 & 3.0 & 1.3 \\
3.0 & 6.4 & 3.1 & 3.5 & 1.2 \\
6.0 & 7.6 & 2.1 & 3.5 & 2.1 \\
9.0 & 7.5 & 2.5 & 3.5 & 2.1 \\
L.S.D. $5 \%$ & 0.7 & 1.1 & 0.33 & 0.37 \\
$1 \%$ & 1.0 & 1.5 & 0.46 & 0.52 \\
\hline
\end{tabular}

Values are means of results from five trees in each case, with the exception of trees that did not receive any added nitrogen. In the latter case, ten trees were examined.

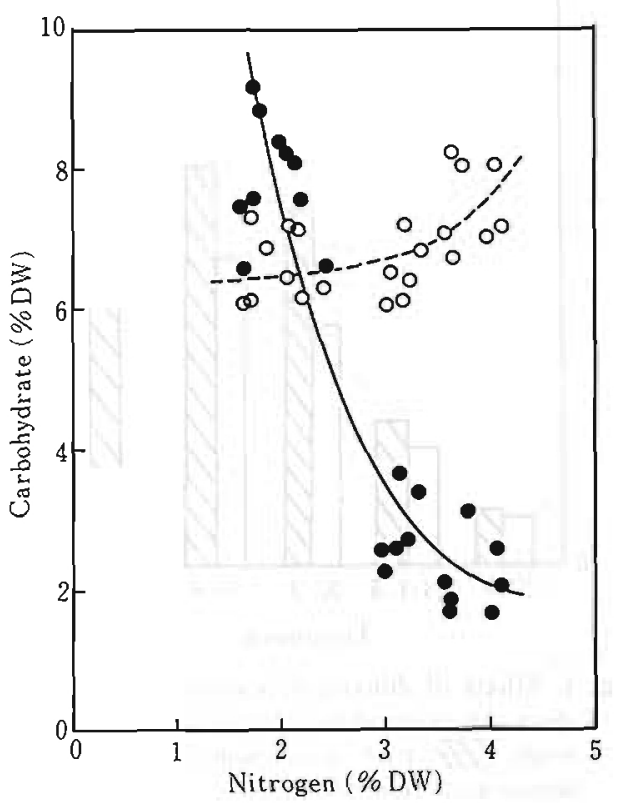

Fig. 2. Relationship between contents of total soluble sugar and starch and the nitrogen content in leaves of peach trees. $\bigcirc$, Total sugar;, starch.

during the second growth cycle during June in the present experiment. Sorbitol content in mature leaves may increase with utilization of other soluble carbohydrates. Conversely, the vegetative growth in $\mathrm{N}-0$ trees was less during June than $\mathrm{N}-3, \mathrm{~N}-6$, and $\mathrm{N}-9$ trees. The sorbitol content might be a reflection of a decreased capacity for sugar export from mature leaves and attributed to the weak sink activity. The sorbitol content of the

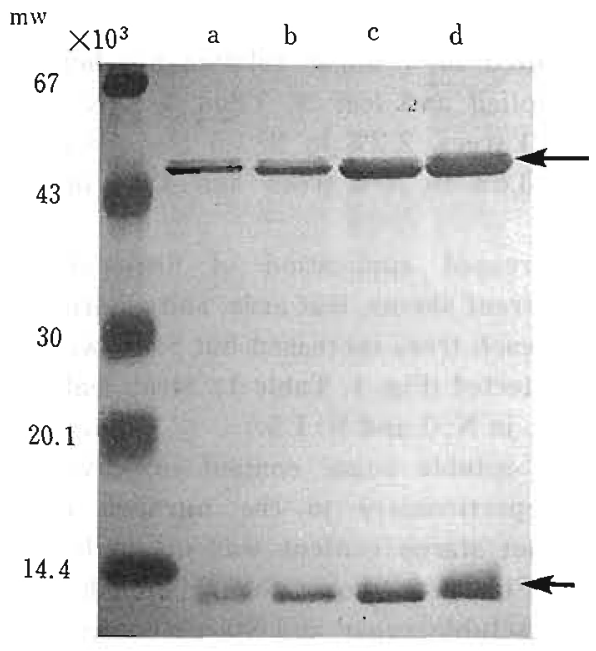

Fig. 3. Gel plate of peach leaf RuBisCO protein, revealed by immunoblotting. An equal volume of sample was loaded in each lane ( $a, N-0$ leaves; $b, N-1.5$ leaves; $c, N-3$ leaves; N-6 leaves). Numerals on the left indicate molecular weights $(\mathrm{mw})$ of pre-stained protein standards run that were subjected to electrophoresis in parallel with samples. Arrows indicate the $\mathrm{L}$ (Large, large arrow) and $S$ (Small, small arrow) subunits of RuBis$\mathrm{CO}$.

leaves of fruiting peach trees during the fruitmaturation stage was higher than that of the leaves of defruited trees (Nii, 1997). These results suggest that sorbitol in leaves increases with the increased demands created by the developing fruit and/or shoots.

Figure 3 shows gels which resulted from immunoblotting peach $\mathrm{RuBis} C \mathrm{O}$ protein after isola- 

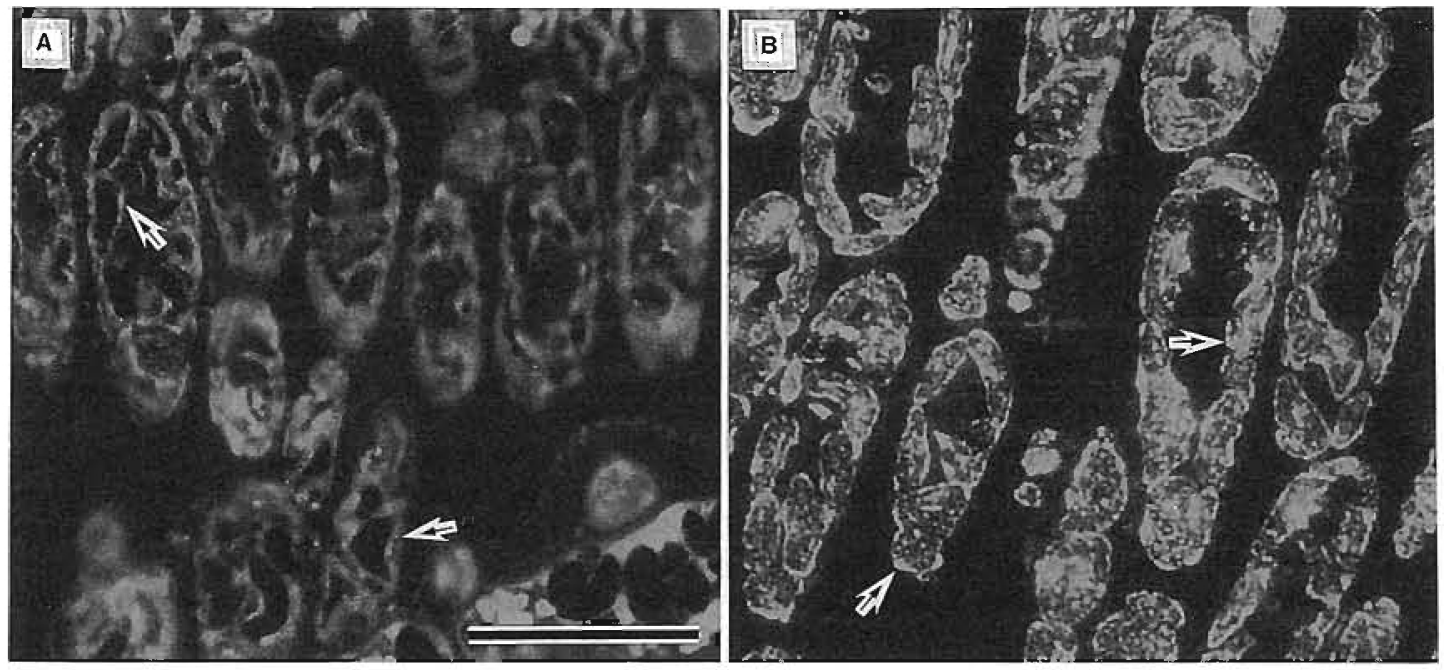

Fig. 4. Immunofluorescence from palisade and spongy tissue of peach leaves after staining with antibodies against RuBisCO from spinach and rhodamine-conjugated second antibody. Arrows point to RuBisCO protein in the chloroplast. A. N-0 leaf. $\mathrm{B}, \mathrm{N}-6$ leaf. $\mathrm{Bar}=20 \mu \mathrm{m}$.

tion by SDS-PAGE. The immunoblot of peach leaf extract probed with monospecific antibodies against $\mathrm{RuBis} C O$ from spinach reveal two immunoreactive bands, which corresponded to the $\mathrm{L}$ and $\mathrm{S}$ subunits of RuBisCO, respectively. This demonstrates that extracts of peach leaves contained proteins that cross-reacted with antibodies against the enzyme from spinach and that the antibodies are applicable for cytochemical analysis of RuBis$\mathrm{CO}$ in peach leaves. These proteins were assumed to be components of RuBisCO. Immunoblot analy. sis also revealed that the contents of the immunoreactive proteins increased markedly as the leaves were supplied with more nitrogen.

The results of immuno-detection after SDS-PAGE were supported by the results of immunocytochemical staining of sections of leaves (Fig. 4). Mesophyll tissue from peach leaves, immunostained with antibodies against RuBisCO from spinach, revealed the distribution of RuBis$\mathrm{CO}$ in the chloroplasts. The intensity of immunoreaction increased with the increase in the amounts of nitrogen applied so that stronger immunoreactivity was detected in the greener and less starchy chloroplasts.

The changes in RuBisCO protein content in response to the application of nitrogen contribute to our understanding the physiological functions of leaves (Evans, 1983, 1989; Evans and Terashima, 1988; Terashima and Evans, 1988; Makino et al., 1992). Increases in the RuBisCO protein content with increased contents of nitrogen in the leaves depend on the plant species; contents of RuBisCO protein were increased by applications of nitrogen in rice, spinach, bean, and pea, whereas it was independent of applied nitrogen in wheat (Makino et al., 1992). In the present studies, $\mathrm{N}-0$ and $\mathrm{N}-1.5$ resulted in decreased $\mathrm{RuBisCO}$ protein and chlorophyll contents and a concurrent increase in starch.

\section{Acknowledgements}

We thank Mr. E. Yokotani and Miss. N. Shinkai for their invaluable assistance. This work was supported in part by a grant from a Grant-in-Aid for Scientific Research from the Ministry of Education, Science and Culture (Japan) and a grant (94-102) from the National Institute for Basic Biology (Japan).

\section{Literature Cited}

Bieleski, R. L. 1969. Accumulation and translocation of sorbitol in apple phloem. Aust. J. Biol. Sci. 22 : 611-620.

DeJong, T. M. 1982. Leaf nitrogen content and $\mathrm{CO}_{2}$ assimilation capacity in peach. J. Amer. Soc. Hort. Sci. $107:$ 955-959. 
DeJong, T. M. 1983. $\mathrm{CO}_{2}$ assimilation characteristics of five Prunus tree fruit species. J. Amer. Soc. Hort. Sci. 108 : 303-307.

DeJong, T. M., A. Tombesi and K. Ryugo. 1984. Photosynthetic efficiency of kiwi (Actinidia chinensis Planch.) in response to nitrogen deficiency. Photosynthetica $18: 139-145$.

DeJong, T. M and J. F. Doyle. 1985. Seasonal relationships between leaf nitrogen content (photosynthetic capacity) and leaf canopy light exposure in peach (Prunus persica). Plant Cell Environ. 8 : $701-706$.

Evans, J. R. 1983. Nitrogen and photosynthesis in the flag leaf of wheat (Triticum aestivum L.). Plant Physiol. 72 : 297-302.

Evans, J. R. 1989. Photosynthesis and nitrogen relationships in leaves of $\mathrm{C}_{3}$ plants. Oecologia 78 : 9-19.

Evans, J. R. and I. Terashima. 1988. Photosynthetic characteristcs of spinach leaves grown with different nitrogen treatments. Plant Cell Physiol. 29 : 157-165.

Gulmon, S. L and C. C. Chu. 1981. The effects of light and nitrogen on photosynthesis, leaf characteristics, and dry matter allocation in the chaparral shrub, Diplacus aurantiacus. Oecology 49 : 207-212.

Hayashi, M., L. D. Bellis, A. Alpi and M. Nishimura. 1995. Cytosolic aconitase participates in the glyoxylate cycle in etiolated pumpkin cotyledons. Plant Cell Physiol. 36 : 669-680.

Kuroiwa, H. 1991. The application of the Technovit embedding method for the research of plant embryology. Plant Morph. 3: 43-47.

Laemmli, V. K. 1970. Cleavage of structural proteins during the assembly of the head of bacteriophage $\mathrm{T}_{4}$. Nature $227: 680-685$.

Layne, D. R. and J. A. Flore. 1993. Physiological responses of Rrunus cerasus to whole-plant source manipulation. Leaf gas exchange, chlorophyll fluorescence, water relations and carbohydrate concentrations. Physiol. Plant. 88 : 44-51.

Layne, D. R and J. A. Flore. 1995. End-product inhibition of photosythesis in Prunus cerasus L. in response to whole-plant source-sink manipulation. J. Amer. Soc. Hort. Sci. 120 : 583-599.

Makino, A., H. Sakashita, J. Hidema, T. Mae, K. Ojima and B. Osmond. 1992. Distinctive responses of ribulose-1, 5-bisphosphate carboxylase and carbon ic anhydrase in wheat leaves to nitrogen nutrition and their possible relationships to $\mathrm{CO}_{2}$-transfer resistance. Plant Physiol. 100 : 1737-1743.

Mooney. H. A., P. J. Ferrar and R. O. Slatyer. 1978. Photosynthetic capacity and carbon allocation patterns in diverse growth forms of Eucalyptus. Oecologia $36: 103-111$.
Nii, N. 1997. Changes of starch and sorbitol in leaves before and after removal of fruits from peach trees. Ann. Bot. $79: 139-144$.

Nii, N., K. Hase and H. Uchida. 1994. Anatomical features on the sieve elements and sorbitol content in various organs of Rosaceae fruit trees. J. Japan. Soc. Hort. Sci. $62: 739-747$.

Nii. N., M. Kato, Y. Hirano and T. Funaguma. 1993. Starch accumlation and photosynthesis in leaves of young peach trees grown under different levels of nitrogen application. J. Japan. Soc. Hort. Sci. 62 : 547-554.

Nii. N., K. Yamaguchi and M. Nishimura. 1995. Effects of fruiting on amylase activity and ribulose bisphosphate carboxylase-oxygenase content in peach leaves. J. Japan. Soc. Hort. Sci. 64 : 267-273.

Nii, N., E. Yokotani and N. Shinkai. 1997. Changes of nonstructural caobohydrate in leaves of apple trees grown after the application of different amounts of nitrogen. Sci. Rept., Fac. Agr., Meijo Univ. 33 : 15-22.

Nishimura, M. and T. Akazawa. 1974. Studies on spinach leaf ribulose bisphosphate carboxylase. Carboxylase and oxygenase reaction examined by immunochemical methods. Biochem. $13: 2271-2281$.

Sawada, S., T. Hayakawa, K. Fukushi and M. Kasai. 1986. Influence of carbohydrates on photosynthesis in single, rooted soybean leaves used as a source-sink model. Plant Cell Physiol. 27 $591-600$.

Sawada, S., H. Kawamura. T. Hayakawa and M. Kasai. 1987. Regulation of photosynthetic metabolism by low-temperature treatment of roots of single-rooted soybean plants. Plant Cell Physiol. 28 : 235-241.

Terashima, I and J. R. Evans. 1988. Effects of light and nitrogen nutrition on the organization of the photosynthetic apparatus in spinach. Plant Cell Physiol. $29: 143-155$.

Tschaplinski, T. J. and T. J. Blake. 1989. The role of sink demand in carbon partitioning and photosynthetic reinvigoration following shoot decapitation. Physiol. Plant. $75:$ 166-173.

Tsugeki R., I. Hara-Nishimura, H. Mori and M. Nishimura. 1993. Cloning and sequencing of cDNA for glycolate oxidase from pumpkin cotyledons and Northern blot analysis. Plant Cell Physiol. 34 : $51-57$.

Webb, K. L. and J. W. A. Burley. 1962. Sorbitol translocation in apple. Science $137: 766$.

Williams, M. W., G. C. Martin and E. A. Stahly. 1967. The movement and fate of sorbitol- $\mathrm{C}^{14}$ in the apple tree and fruit. Proc. Amer. Soc. Hort. Sci. 90 : 20-24.

Williams, L. E. and R. J. Smith. 1985. Net $\mathrm{CO}_{2}$ assimilation rate and nitrogen content of grape leaves subsequent to fruit harvest. J. Amer. Soc. Hort. Sci. 110 : 
$846-850$.

Wintermans, J. F. G. M. and D. A. De Mots. 1965. Spectrophotometric characteristics of chlorophylls and their pheophytins in ethanol. Biochim. Biophys. Acta $109: 448-453$.

\title{
窒素施肥量の相違がモモ葉の炭水化物含量と RuBisCO タンパク質量に及ぼす影響
}

\author{
新居 直祐 ${ }^{1} \cdot$ 山口 勝司 ${ }^{2} \cdot$ 西村 幹夫 $^{2}$ \\ 1 名城大学農学部 468 名古屋市天白区 \\ ${ }^{2}$ 基礎生物学研究所 444 岡崎市明大寺町
}

\begin{abstract}
摘 要
モモの幼木（“大久保” 3 年生未結実樹）を用いて， 窒素施肥量の相違が葉の形質と炭水化物含量, RuBisCO タンパク質量に及ぼす影響を調查した。無空素区 と $1.5 \mathrm{~g} /$ ポット区の葉の窒素含量（乾物重％) は效素 施肥量が多い処理区より低く，無窒素区が $1.8 \%$ であ るのに対して $9 \mathrm{~g}$ 区は $4.0 \%$ であった．単位面積当たり のクロロフィル含量は䇪素施肥量の増加とともに増大 した，無塋素区と $1.5 \mathrm{~g}$ 区の葉のデンプン含量（乾物 重％）は窒素施肥量の多い処理区の葉より有意に高

かった：菜の全糖含量は葉の窒素含畐の增加とともに わずかに高くなる傾向がみられたが，デンプン含量に 対する影瑤に比べて処理区間の差は小さかった，葉の ソルビトールとスクロース含量（新鮮重％）は無峌素 区でもっとも低かった. RuBisCOタンパク質量は, SDS-PAGEによる電気泳動法とホウレンソウ葉の RuBisCO の特異抗体を用いたイムノブロット法と抗体 染色法によって検討した．その結果，RuBisCOタンパ ク質量は窒素施肥量の増加とともに增大した。
\end{abstract}

